\title{
Status of Cassava (Manihot Esculenta Crantz) in Côte d'Ivoire: From Production to Consumption and Evaluation of Technology Adoption
}

\author{
Dr. Kouassi Kan Modeste \\ Unité de Formation et de Recherche en Biosciences (UFR Biosciences), \\ Laboratoire de Physiologie Végétale, Université Félix HOUPHOUËT- \\ BOIGNY (UFHB), Abidjan, Côte d'Ivoire \\ Dr. Mahyao Adolphe \\ Dr. N'zue Boni \\ Dr. Koffi Edmond \\ Dr. Koffi Camille \\ Centre National de Recherche Agronomique (CNRA), Côte d'Ivoire
}

Doi: 10.19044/esj.2018.v14n9p285 URL:http://dx.doi.org/10.19044/esj.2018.v14n9p285

\begin{abstract}
The current state of cassava production and technology level as well as commercialization and consumption aspects were studied in Côte d'Ivoire. The study involved a sample of 570 actors of the value chain randomly selected in three (3) agro ecological regions (south, west and centre). Using a baseline survey questionnaire, 150 producers, 195 transformers and 195 consumers were interviewed. Results showed that farmers and consumers households are in majority led by men ( 80 and 61\%) while transformers households are led by women $(81 \%)$. Concerning the level of adoption of cassava technologies, it was found that about $35 \%$ of cassava growers are aware about the new cassava varieties and more than $80 \%$ agreed to use them. The analysis performed in agro ecological regions revealed that traditional varieties are preferred (40 \% to $90 \%$ ) to improved varieties. Improved varieties, Bocou 1 (10.67\%), TMS4 (2)1425 (0.67\%) and Bocou $2(0.67 \%)$ are less preferred for cultivation in spite of high yields, food processing or taste qualities, respectively mentioned by farmers. More than $50 \%$ of farmers agreed to adopt the Rapid Seed Multiplication technique. Contrary to the localities of Man (West) and Bonoua (South) where pounded cassava is more consumed (89.29\% and 66\%), dehydrated cassava (Attieke) food is the most consumed in other localities surveyed. In spite of the high yield of improved varieties and the desire of cassava growers to adopt new cassava technologies,
\end{abstract}


research and extension services should be reinforced taking into account agro ecological specificities of production, commercialization and consumption.

Keywords: Cassava farming, improved varieties, technology adoption, agro ecological region, Côte d'Ivoire

\section{Introduction}

Cassava is the most important crop in Africa by both production weight and value, and it provides a similar source of calories as rice. Its drought-tolerance, resilience on marginal agricultural land, and ability to be stored in the ground up to three years make it an important food security crop for smallholder farmers (IFAD \& FAO, 2000; Sayre, Beeching, Cahoon, Egesi, Fauquet, Fellman \& Zhang, 2011). Cassava is a staple and also a famine reserve crop and can be an important food source when drought and conflict prevent production of other food crops (Burns, Gleadow, Cliff, Zacarias \& Cavagnaro, 2010). An estimated $40 \%$ of Africans rely on the crop as a significant source of calories (Nweke, 2004).

Total world cassava use is expected to increase from 172.7 million to 273 million $t$ in the period 1993-2020 using the International Food Policy Research Institute's (IFPRI's) baseline data. A higher prediction of demand and production growth estimates the 2020 production at 291 million $\mathrm{t}$ (Scott, Rosegrant \& Ringler, 2000). In both projections cassava use in Africa is equivalent to $62 \%$ of total world production. The sub-Saharan region is one of the most producing parts in Africa. For proof, West Africa produced 80.9 million metric tons of cassava in 2012, accounting for 54.15\% of African global production. This is justified by the geographic situation of Nigeria - the world biggest producer (FAO, 2013). In fact, the world production was 278,754 million tonnes in 2016. The part of Africa was 155398 million tonnes of which 57855 million were produced by Nigeria, making it the world's largest producer With 4548 million tonnes, Côte d'Ivoire was the 13rd producer in Africa (FAO, 2017).

In Côte-d'Ivoire, cassava is the second largest food crop after yam. It is grown throughout the country. The southern zone is the area of high production (N'zué, Okoma, Kouakou, Dibi, Zohouri, Essis, \& Dansi, 2014). In order to improve cassava production and access to planting material, new varieties developed through research as well as new methods of producing and propagating plant material have been made available to actors in the cassava sector. Farmers have taken up three high-yielding varieties of cassava, known as Bocou1, Bocou2, Bocou3 and TmS4(2)1425 resistant to disease and pests. These varieties can produce 32 to 34 tonnes per hectare per year, compared to less than 20 tonnes per hectare from traditional cassava varieties (N'zué, Zohouri, Djédji \& Tahou, 2013). In addition, the rapid seed mutiplication 
method has been familiarized (N'zué, Zohouri, Doumbia, Yapi-Gnaoré \& Sangaré, 2008).

The current study assesses the adoption of these innovations or technologies by the actors of cassava value chain. It aims at selecting the elite seeds suitable for the specific region and -specific environments of Côte d'Ivoire and also evaluates through the value chain, the current state of production as well as constraints in the dissemination of high quality seeds.

\section{Methodology Study sites}

Six (6) sites (localities) were selected in three (3) agro ecological regions: West (Man), Centre (Bouaké) and South (Dabou, Bingerville and Bonoua) of Côte d'Ivoire for this baseline survey during June 2016. The West region has a mountain climate (with precipitation from 1500 to $2200 \mathrm{~mm} /$ year and two seasons: a dry and a rainy). The Centre has an attenuated equatorial transition climate (with precipitation from 1500 to $2200 \mathrm{~mm} / \mathrm{year}$ and four seasons: two dry and two rainy). The South has an equatorial transition climate (with precipitation from 1300 to $2400 \mathrm{~mm} /$ year and four seasons: two dry and two rainy). The criteria of selection of the six sites were the importance of cassava yield, the processing or commercialization and the consumption as well as the level of technology in diffusion. The three (3) treatments sites for technology diffusion located in West (Man), Centre (Bouake) and South (Dabou) regions were compared to two (2) controls sites selected in the South region (Bingerville and Bonoua) where improved varieties are not yet disseminated to farmers. Abidjan was the sixth site surveyed for a high level of cassava consumption.

\section{Introduced technologies}

In Côte d'Ivoire, five (5) technologies were developed and introduced in cassava fields by the National Center for Agronomic Research (CNRA) and ANADER (Agence Nationale d'Appui au Développement Rural). These technologies involved four (4) improved varieties (Bocou1, Bocou 2, Bocou 3 and TMS4 (2)1425) and a technology referred as Rapid Seed Multiplication by rationing $(\mathrm{RSM})$.

\section{Data collected and analysis}

The study sample of 540 actors composed of 150 producers, 195 transformers and 195 consumers were surveyed by questionnaires. The variables investigated were about socio-demographic characteristics of households (sex, age, origin, education and years of experience), Farm management and cultural practices (varieties cultivated and/or preferred, frequencies of cultivation, farm size, periods and frequency of harvesting, 
yields), marketing and processing activity (derived products, markets and prices), the use of new technologies and Cassava consumption level (processed products and frequency of consumption). The analysis was especially based on descriptive statistics. The STATA statistical software was used for data analysis.

\section{Results and discussion}

\section{Socio-demographic characteristics of households}

Socio-demographic characteristics of households led by actors involved in the cassava value chain were presented in Table 1.

Farmers and consumers' households were in majority led by men ( 80 and $61 \%$ ) while transformers households were led by women $(81 \%)$. On average, heads of farm families (44 years) and transformers (45 years) were younger than consumers (49 years). A high proportion of heads of households were autochthons $(58 \%$ of farmers, $76 \%$ of transformers and $66 \%$ of consumers), illiterates (43\% of farmers; $36 \%$ of transformers and $33 \%$ of consumers) and married (82\% of farmers; $62 \%$ of transformers and $69 \%$ of consumers). Non-native (31\%) were most present in cassava farming than in processing (1\%). On average, eight (8) members were found in cassava farm families as well as in transformer's and consumer's families. Five (05) among them worked in production and processing while three (03) in marketing. Producers and processors had approximately the same length of experience (13 and 14 years). Producers combined the two activities of production and marketing (61\%) and also the three activities of production, processing and marketing $(29 \%)$ while processors were specialized in both processing and marketing $(44 \%)$ or marketing $(32 \%)$.

The households led by cassava value chain actors are headed by adults men, illiterate with more than ten years of experience in their activities. The analysis revealed similar socio-demographic characteristics of farm families with transformer's families which corroborate with the state of combine function between cassava growers and transformers.

Table 2 : Socio-demographic characteristics of cassava value chain actors interviewed in Côte d'Ivoire

\begin{tabular}{lllll}
\hline $\begin{array}{l}\text { Variables } \\
\text { (units) }\end{array}$ & Modality & Farmers & Transformers & Consumers \\
\hline Sex (\%) & Men & 80 & 18.97 & 61.54 \\
& Women & 20 & 81.03 & 38.46 \\
\hline Age (years) & Min & 18 & 19 & 25 \\
& Max & 88 & 85 & 96 \\
& Mean & 44.23 & 45.19 & 48.79 \\
\hline Origin (\%) & Autochthons & 58.22 & 76.04 & 66.49 \\
& Allochthons & 10.96 & 22.92 & 23.56 \\
& Non native & 30.82 & 1.04 & 9.95 \\
\hline Education (\%) & None & 43.24 & 35.90 & 32.99 \\
& Primary & 29.05 & 37.95 & 26.29
\end{tabular}




\begin{tabular}{|c|c|c|c|c|}
\hline & Secondary & 23.65 & 25.13 & 31.96 \\
\hline & University & 4.05 & 1.03 & 8.76 \\
\hline \multirow{4}{*}{$\begin{array}{l}\text { Marital status } \\
(\%)\end{array}$} & Married & 82.43 & 61.98 & 69.27 \\
\hline & Single & 13.51 & 23.96 & 18.75 \\
\hline & Divorced & 0.00 & 2.08 & 2.08 \\
\hline & Widower/Widow & 4.05 & 11.98 & 9.90 \\
\hline \multicolumn{5}{|l|}{$\begin{array}{l}\text { Household } \\
\text { size (Number) }\end{array}$} \\
\hline \multirow[t]{3}{*}{ Wives } & Min & 0 & 0 & 0 \\
\hline & Max & 4 & 8 & 8 \\
\hline & Mean & 1.07 & 1.59 & 1.28 \\
\hline \multirow[t]{3}{*}{ Children } & Min & 0 & 1 & 0 \\
\hline & Max & 24 & 16 & 18 \\
\hline & Mean & 5.30 & 4.96 & 4.92 \\
\hline \multirow{3}{*}{$\begin{array}{l}\text { Children } \\
\text { solarized }\end{array}$} & Min & 0 & 0 & 0 \\
\hline & Max & 9 & 10 & 10 \\
\hline & Mean & 2.92 & 3.17 & 2.98 \\
\hline \multirow[t]{3}{*}{ Total } & Min & 1 & 2 & 2 \\
\hline & Max & 29 & 27 & 30 \\
\hline & Mean & 7.80 & 7.69 & 7.98 \\
\hline \multicolumn{5}{|l|}{$\begin{array}{l}\text { Laborers size } \\
\text { (Number) }\end{array}$} \\
\hline \multirow[t]{3}{*}{ Permanent } & Min & 0 & 0 & - \\
\hline & Max & 16 & 20 & - \\
\hline & Mean & 2.80 & 2.20 & - \\
\hline \multirow{3}{*}{$\begin{array}{l}\text { Non- } \\
\text { permanent }\end{array}$} & Min & 0 & 0 & - \\
\hline & Max & 20 & 30 & - \\
\hline & Mean & 4.00 & 2.53 & - \\
\hline \multirow[t]{3}{*}{ Total } & Min & 0 & 0 & - \\
\hline & Max & 21 & 30 & - \\
\hline & Mean & 5.28 & 3.21 & - \\
\hline \multirow{3}{*}{$\begin{array}{l}\text { Experience } \\
\text { (Years) }\end{array}$} & Min & 1 & 3 & - \\
\hline & Max & 50 & 40 & - \\
\hline & Mean & 13.06 & 14.37 & - \\
\hline \multirow{7}{*}{$\begin{array}{l}\text { Main activity } \\
(\%)\end{array}$} & Production & 9.46 & - & - \\
\hline & Trading & - & 32.11 & - \\
\hline & Processing & - & 7.89 & - \\
\hline & $\begin{array}{l}\text { Production, } \\
\text { Trading }\end{array}$ & 61.49 & 9.47 & - \\
\hline & Processing, & - & 43.68 & - \\
\hline & Trading & & & \\
\hline & $\begin{array}{l}\text { Production, } \\
\text { Processing, } \\
\text { Trading }\end{array}$ & 29.06 & 6.84 & - \\
\hline
\end{tabular}

\section{Farm characteristics, technology adoption and production}

Table 2 shows the situation of cultivated and preferred varieties by farmers in Côte d'Ivoire. The three (3) most cultivated varieties were nonimproved (or traditional) varieties Yace (54\%), Agba ble (13.33\%) and 
Essakpel (6.67\%), respectively preferred by farmers according to high market demand $(38 \%)$, good quality for food processing $(16 \%)$ and the precocity of cycle $(8 \%)$ of production. The study revealed also that improved varieties were less preferred (Bocou 1 (10.67\%), TMS4 (2)1425 (0.67\%) and Bocou 2 $(0.67 \%))$ for cultivation in spite of high yields, food processing or taste qualities, respectively mentioned by farmers. The global analysis showed that low utilization of improved varieties in cassava farming was probably due to competitiveness of traditional varieties and differences of adaptability between agro ecological regions. The second reason might be the fact that improved varieties were recently released, since 2010 .

The analysis within agro ecological regions as shown in Table 3 revealed that the first variety preferred (Yace) is most preferred in the South (Bingerville (90\%), Bonoua (50\%) and Dabou (30\%)) and the West (Man $(36.67 \%)$ ) regions while the second variety (Agba ble) is preferred in the Centre (Bouake $(80 \%)$ ) of the country. Within agro ecological regions, it was found that the level of improved varieties cultivated was higher with Bocou 1 (33.33\% in Dabou) conversely to TMS4 (2)1425) (3.33\% in Man) and Bocou 2 ( $0 \%$ in Dabou). The variety Bocou 3 is not yet cultivated by farmers.

Results on the level of adoption of cassava technologies in Côte d'Ivoire were presented in Table 4 . It was found that about $35 \%$ of cassava growers were awarded of new cassava varieties and more than $80 \%$ agreed to use them. The analysis revealed also that the level of knowledge varied within agro ecological regions. Percentages of knowledge in treatment regions (where technologies were introduced) varied from $21 \%$ in the West (Man) to $47 \%$ in the Centre (Bouake) and $90 \%$ in the South (Dabou) while in control regions (where technologies were not yet introduced), the level varied from $15 \%$ in Bingerville to $100 \%$ in Bonoua both located in the south region. It was also found that more than $50 \%$ of cassava growers agreed to use new varieties. The RSM technique is also well known in treatments regions (23 to 79\%) as well as in controls (28 to $100 \%$ ) where more than $50 \%$ of farmers agreed to use it.

There was a large willingness of producers to adopt new varieties but the allocated areas were still weak. The total average area has been 0.74 ha with variation between varieties from Bocou 2 (0.16 ha cultivated in Dabou) to TMS4 (2)1425 (0.87 ha in Man) and Bocou1 (1 ha in Bouake and 0.46 ha in Dabou). The average density of plantation was 769 plants/ha (representing $7.69 \%$ of the area) associated with variation from TMS4 (2)1425 (550 plants/ha: $5.5 \%$ of the area) to Bocou1 (878 plants/ha: $8.78 \%$ of the area) and Bocou2 (881 plants/ha: $8.81 \%$ of the area).

This study has revealed that improved varieties were less used for cultivation. Coulibaly, Arinloye, Faye \& Abdoulaye, (2014) indicated that varieties Bocou 1, Bocou 2 and Bocou 3 had been taken up by farmers in the 
southern and eastern parts of the country. This study showed that, in fact, these varieties were well received by the populations. Their adoption should take longer. The global analysis of technology adoption in cassava farming revealed that non-improved varieties were still cultivated and preferred by farmers. In spite of the great desire of the producers to use new varieties, the level of adoption was still low in practice in different agro ecological regions of Côte d'Ivoire. The reasons of less-utilization of new technologies were due to the Low Yield Dry Matter (LYDM) of new varieties (Bocou 1, Bocou 2 and Bocou 3) and the non-knowledge of TMS4 (2)1425). Awareness on improved varieties and technology for rapid seed multiplication should be reinforced. It has been commonly shown that acceptance of new technology practices take place over time (Nweke, 1994). Adoption was said to be the continued use of innovation after individuals have passed through certain mental processes. The adoption of improved technology was influenced by various factors such as; personal characteristics, traditional believes, institutional and socio economic factors (Suleman, 2012). It could also be explained through different processes such as awareness, interest, evaluation and trial (Suleman 2012 ; Ekong, 2003 ; Agbamu, 2006). Yusuf (2009) found the rate of adoption of improved technologies was higher when the technologies were easy to operate.

Table 3 : Cassava varieties cultivated and preferred by farmers in Côte d'Ivoire

\begin{tabular}{lllll}
\hline \multicolumn{1}{c}{$\begin{array}{c}\text { Variety } \\
\text { Name }\end{array}$} & \multicolumn{1}{c}{$\begin{array}{c}\text { Variety } \\
\text { Type }\end{array}$} & \multicolumn{1}{c}{$\begin{array}{c}\text { Cultivation } \\
(\boldsymbol{\%})\end{array}$} & \multicolumn{1}{c}{$\begin{array}{c}\text { Preference } \\
(\boldsymbol{\%})\end{array}$} & \multicolumn{1}{c}{ Reasons of preference } \\
\hline Yace & Traditional & 54.00 & 38.00 & High market demand \\
Agbable & Traditional & 13.33 & 16.00 & Food processing \\
Essakpel & Traditional & 6.67 & 8.00 & Precocity cycle \\
Bocou $\mathbf{1}$ & Improved & $\mathbf{6 . 0 0}$ & $\mathbf{1 0 . 6 7}$ & High yield \\
Akra batchin & Traditional & 3.33 & 8.00 & High yield, Food \\
& & & & processing \\
Assuable & Traditional & 3.33 & 0.67 & Taste \\
Tambou & & & & \\
Dabou & Traditional & 2.67 & 10.67 & Precocity cycle \\
Zoglo ble & Traditional & 2.67 & 2.00 & Food processing \\
Sans manquer & Traditional & 2.00 & 0.67 & - \\
Vitesse & Traditional & 2.00 & 0.67 & High market demand \\
Bonoua & Traditional & 1.33 & 0.67 & Food processing, Taste \\
TMS & Improved & $\mathbf{0 . 6 7}$ & $\mathbf{0 . 6 7}$ & Food processing \\
Manioc doux & Traditional & 0.67 & 0.67 & - \\
Okou & Traditional & 0.67 & 0,67 & - \\
Tetoh & Traditional & 0.67 & 0.67 & Taste \\
Bocou 2 & Improved & - & $\mathbf{0 . 6 7}$ & High yield, Taste \\
Alidja & Traditional & - & 0.67 & High yield \\
Mantale & Traditional & - & 0.67 & High yield, Food \\
Yavo & Traditional & - & & processing \\
You M'bossi & Traditional & - & 0.67 & Food processing, Taste \\
\hline Total & & 100.00 & 100.00 & \\
\hline
\end{tabular}


Table 4 : Cassava varieties cultivated and preferred in agro-ecological region in Côte d'Ivoire

\begin{tabular}{|c|c|c|c|c|c|c|}
\hline $\begin{array}{c}\text { Agro- } \\
\text { Ecological } \\
\text { Region }\end{array}$ & $\begin{array}{l}\text { Locality } \\
\text { Name }\end{array}$ & $\begin{array}{l}\text { Variety } \\
\text { Name }\end{array}$ & $\begin{array}{l}\text { Variety } \\
\text { Type }\end{array}$ & $\begin{array}{r}\text { Cultivation } \\
(\%)\end{array}$ & $\begin{array}{r}\text { Preference } \\
(\%)\end{array}$ & Reason of utilisation \\
\hline \multirow[t]{5}{*}{ West } & $\operatorname{Man}^{1}$ & Bocou 1 & Improved & - & 3.33 & High market demand \\
\hline & & TMS & Improved & 3.33 & 3.33 & Food processing \\
\hline & & Dabou & Traditional & 13.33 & 53.33 & Precocity cycle \\
\hline & & Tetoh & Traditional & 3.33 & 3.33 & Taste \\
\hline & & Yace & Traditional & 80.00 & 36.67 & High market demand \\
\hline \multirow[t]{6}{*}{ Centre } & Bouake $^{1}$ & Bocou 1 & Improved & 6.67 & 13.33 & Food processing \\
\hline & & Agbable & Traditional & 66.67 & 80.00 & Food processing \\
\hline & & Bonoua & Traditional & 6.67 & - & \\
\hline & & Okou & Traditional & 3.33 & - & \\
\hline & & Yace & Traditional & 3.33 & 3.33 & Food processing \\
\hline & & Zoglo ble & Traditional & 13.33 & 3.33 & Food processing \\
\hline \multirow[t]{9}{*}{ South } & Dabou $^{1}$ & Bocou 1 & Improved & 33.33 & 36.67 & High yield \\
\hline & & Bocou 2 & Improved & - & 3.33 & High yield \\
\hline & & Bonoua & Traditional & & 3.33 & Food processing, Taste \\
\hline & & Essakpel & Traditional & 23.33 & 40.00 & Precocity cycle \\
\hline & & Manioc doux & Traditional & 3.33 & - & \\
\hline & & Sans manq. & Traditional & 10.00 & - & \\
\hline & & Yace & Traditional & 30.00 & 10.00 & High yield, Food process. \\
\hline & & Yavo & Traditional & - & 3.33 & High yield \\
\hline & & You M’Bossi & Traditional & - & 3.33 & Food processing \\
\hline \multirow[t]{8}{*}{ South } & Bonoua $^{2}$ & Akra batchin & Traditional & 16.67 & 40.00 & High yield \\
\hline & & Assuable T. & Traditional & 16.67 & 3.33 & Taste \\
\hline & & Mantale & Traditional & - & 3.33 & High yield, Food process. \\
\hline & & Vitesse & Traditional & 10.00 & 3.33 & High market demand \\
\hline & & Yace & Traditional & 56.67 & 50.00 & High yield \\
\hline & ${ }_{2}$ Bingerville & Alidja & Traditional & - & 6.67 & High yield \\
\hline & & Yace & Traditional & 100.00 & 90 & High market demand \\
\hline & & Zoglo ble & Traditional & - & 3.33 & Food processing, Precocity \\
\hline
\end{tabular}

${ }^{1}$ Treatment site where improved cassava varieties were introduced, ${ }^{2}$ Control site Sans manq. $=$ Sans manquer $;$ AssuableT.$=$ Assuable Tambou

Table 5 : Cassava technologies adoption in agro ecological regions of Côte d'Ivoire

\begin{tabular}{|c|c|c|c|c|c|c|c|c|}
\hline $\begin{array}{l}\text { Agro- } \\
\text { Ecological } \\
\text { Region }\end{array}$ & $\begin{array}{l}\text { Locality } \\
\text { Name }\end{array}$ & Variables (units) & $\begin{array}{l}\text { Bocou } \\
1\end{array}$ & $\begin{array}{l}\text { Bocou } \\
2\end{array}$ & $\begin{array}{l}\text { Bocou } \\
3\end{array}$ & TMS & Pooled & $\mathrm{RSM}^{1}$ \\
\hline \multirow[t]{6}{*}{ West } & \multirow[t]{6}{*}{ Man } & Knowledge technology (\%) & - & - & - & - & 21.43 & 79.31 \\
\hline & & Agree for utilisation (\%) & - & - & - & - & 90.00 & 90.48 \\
\hline & & Area (ha) & - & - & - & 0.87 & 0.87 & - \\
\hline & & Plants (Number/ha) & - & - & - & 550 & 550 & - \\
\hline & & Improved seeds uses $(\%)$ & - & - & - & - & 3.33 & - \\
\hline & & Reason $^{2}$ non-use technology & LY & HPW & LYDM & UT & - & UT \\
\hline
\end{tabular}




\begin{tabular}{|c|c|c|c|c|c|c|c|c|}
\hline \multirow[t]{6}{*}{ Centre } & \multirow[t]{6}{*}{ Bouake } & Knowledge technology (\%) & - & - & - & - & 46.67 & 23.33 \\
\hline & & Agree for utilisation (\%) & - & - & - & - & 56.67 & 57.14 \\
\hline & & Area (ha) & 1 & - & - & - & 1 & - \\
\hline & & Plants (Number/ha) & 17 & - & - & - & 17 & - \\
\hline & & Improved seeds uses (\%) & - & - & - & - & 3.33 & - \\
\hline & & Reason non-use technology & LYDM & LY & - & - & - & UT \\
\hline \multirow[t]{6}{*}{ South } & \multirow[t]{6}{*}{ Dabou } & Knowledge technology (\%) & - & - & - & - & 89.66 & 67.86 \\
\hline & & Agree for utilisation $(\%)$ & - & - & - & - & 96.55 & 78.95 \\
\hline & & Area (ha) & 0.46 & 0.16 & - & - & 0.31 & - \\
\hline & & Plants (Number/ha) & 1311 & 881 & - & - & 1096 & - \\
\hline & & Improved seeds uses (\%) & - & - & - & - & 23.33 & - \\
\hline & & Reason non-use technology & - & - & - & UT & - & LL \\
\hline \multirow[t]{6}{*}{ South } & \multirow[t]{6}{*}{ Bonoua } & Knowledge technology (\%) & - & - & - & - & 100.00 & 100.00 \\
\hline & & Agree for utilisation $(\%)$ & - & - & - & - & 90.00 & - \\
\hline & & Area (ha) & - & - & - & - & - & - \\
\hline & & Plants (Number/ha) & - & - & - & - & - & - \\
\hline & & Improved seed uses $(\%)$ & - & - & - & - & 0 & - \\
\hline & & Reason non-use technology & $\mathrm{LL}$ & - & - & - & - & - \\
\hline \multirow[t]{6}{*}{ South } & \multirow[t]{6}{*}{ Bingerville } & Knowledge technology $(\%)$ & - & - & - & - & 15.38 & 27.59 \\
\hline & & Agree for utilisation $(\%)$ & - & - & - & - & 100.00 & 83.33 \\
\hline & & Area (ha) & - & - & - & - & - & - \\
\hline & & Plants (Number/ha) & - & - & - & - & - & - \\
\hline & & Improved seeds uses $(\%)$ & - & - & - & - & 0 & - \\
\hline & & Reason non-use technology & - & - & - & - & - & - \\
\hline \multirow[t]{6}{*}{ Pooled } & \multirow[t]{6}{*}{-} & Knowledge technology $(\%)$ & - & - & - & - & 34.97 & 40.43 \\
\hline & & Agree for utilisation $(\%)$ & - & - & - & - & 86.58 & 81.13 \\
\hline & & Area (ha) & 1.19 & 0.16 & - & 0.87 & 0.74 & - \\
\hline & & Plants (Number/ha) & 878.4 & 881 & - & 550 & 769.80 & - \\
\hline & & Improved seeds uses (\%) & - & - & - & - & 6.00 & - \\
\hline & & Reason non-use technology & LYDM & LYDM & LYDM & UT & - & UT \\
\hline
\end{tabular}

${ }^{1} \mathrm{RSM}=$ Technology for Rapid Seed Multiplication

${ }^{2}$ LYDM $=$ Low Yield Dry Matter, LL = Lack of Land, LY = Low Yield, UT = Unknown

Technology

\section{Current state of cassava production}

Basing on data collected during the three (3) past years of cassava production, the current state of production was estimated and results were presented in Table 5.

Estimation showed an average yield of cassava of 16.03 Tons/ha/year with area of cultivation of 1.48 ha per producer. Areas of production varied from 0.33 to 8 ha. The highest yield was observed in the South (20.75 Tons/ha in Bonoua) and the lowest in the Centre (9.63 tons/ha in Bouake) and intermediate values observed in the South (10.61 Tons/ha in Dabou and 11.34 Tons/ha in Bingerville) and in the West (15.17 tons/ha in Man). 
With regard to the cassava production, referencing to the average yield (15 and 33 tons/ha) that could be obtained for improved varieties in rural areas (according to CNRA, 2014), the study revealed that the current state of cassava production was low. The landraces were often low yield potential. The level of cassava technology adoption in Côte d'Ivoire was actually low. Therefore, producers should cultivate high yield landraces and new improved varieties and landraces

Table 6 : Cassava average yields in agro ecological regions of Côte d'Ivoire

\begin{tabular}{|c|c|c|c|c|c|c|c|c|c|}
\hline $\begin{array}{l}\text { Agro- } \\
\text { Ecological } \\
\text { Region }\end{array}$ & $\begin{array}{l}\text { Locality } \\
\text { Name }\end{array}$ & $\begin{array}{l}\text { Cropping } \\
\text { years }^{1}\end{array}$ & $\begin{array}{l}\text { Min } \\
\text { area } \\
\text { (ha) }\end{array}$ & $\begin{array}{l}\text { Max } \\
\text { area } \\
\text { (ha) }\end{array}$ & $\begin{array}{l}\text { Mean } \\
\text { area } \\
\text { (ha) }\end{array}$ & $\begin{array}{l}\text { Number } \\
\text { harvests/ } \\
\text { year }\end{array}$ & $\begin{array}{l}\text { Number } \\
\text { Vehicles } / \\
\text { year }\end{array}$ & $\begin{array}{l}\text { Quantity } \\
\text { harvested } \\
\text { (Tons/year) }\end{array}$ & $\begin{array}{l}\text { Yield } \\
\text { (Tons/ha/ } \\
\text { year) }\end{array}$ \\
\hline \multirow[t]{4}{*}{ West } & \multirow[t]{4}{*}{ Man } & $2013 / 2014$ & 0.50 & 1.50 & 0.85 & 13.95 & 3.52 & 10.56 & 12.42 \\
\hline & & $2014 / 2015$ & 0.50 & 1.00 & 0.75 & 11.42 & 3.52 & 10.56 & 14.08 \\
\hline & & $2015 / 2016$ & 0.50 & 1.00 & 0.80 & 13.61 & 5.07 & 15.21 & 19.01 \\
\hline & & $\begin{array}{l}\text { Yearly } \\
\text { average }\end{array}$ & 0.50 & 1.17 & 0.80 & 12.99 & 4.04 & 12.11 & 15.17 \\
\hline \multirow[t]{4}{*}{ Centre } & \multirow[t]{4}{*}{ Bouake $^{1}$} & $2013 / 2014$ & 0.25 & 2.00 & 0.78 & 2.00 & 2.00 & 6.00 & 7.69 \\
\hline & & $2014 / 2015$ & 0.50 & 2.00 & 0.84 & 2.00 & 3.50 & 10.50 & 12.5 \\
\hline & & $2015 / 2016$ & 0.50 & 2.00 & 0.72 & 2.50 & 2.09 & 6.27 & 8.70 \\
\hline & & $\begin{array}{l}\text { Yearly } \\
\text { average }\end{array}$ & 0.42 & 2.00 & 0.78 & 2.17 & 2.53 & 7.59 & 9.63 \\
\hline \multirow[t]{4}{*}{ South } & \multirow[t]{4}{*}{ Dabou $^{1}$} & $2013 / 2014$ & 0.07 & 1.50 & 0.58 & 6.27 & 2.23 & 6.69 & 11.53 \\
\hline & & $2014 / 2015$ & 0.07 & 2.00 & 0.67 & 6.76 & 2.16 & 6.48 & 9.67 \\
\hline & & $2015 / 2016$ & 0.09 & 1.50 & 0.59 & 6.50 & 2.09 & 6.27 & 10.62 \\
\hline & & $\begin{array}{l}\text { Yearly } \\
\text { average }\end{array}$ & 0.08 & 1.67 & 0.61 & 6.51 & 2.16 & 6.48 & 10.61 \\
\hline \multirow[t]{4}{*}{ South } & \multirow[t]{4}{*}{ Bonoua $^{2}$} & $2013 / 2014$ & 0.25 & 10.00 & 1.83 & 1.00 & 12.70 & 38.10 & 20.81 \\
\hline & & $2014 / 2015$ & 0.25 & 8.00 & 1.52 & 1.00 & 10.46 & 31.38 & 20.64 \\
\hline & & $2015 / 2016$ & 0.50 & 6.00 & 1.60 & 1.00 & 11.10 & 33.30 & 20.81 \\
\hline & & $\begin{array}{l}\text { Yearly } \\
\text { average }\end{array}$ & 0.33 & 8.00 & 1.65 & 1.00 & 11.42 & 34.26 & 20.75 \\
\hline \multirow[t]{4}{*}{ South } & \multirow[t]{4}{*}{ Bingerville $^{2}$} & $2013 / 2014$ & 1.00 & 5.00 & 1.63 & 3.16 & 6.58 & 19.74 & 12.11 \\
\hline & & $2014 / 2015$ & 0.25 & 5.00 & 1.85 & 3.04 & 5.54 & 16.62 & 8.98 \\
\hline & & $2015 / 2016$ & 1.00 & 6.00 & 2.05 & 3.62 & 8.83 & 26.49 & 12.92 \\
\hline & & $\begin{array}{l}\text { Yearly } \\
\text { average }\end{array}$ & 0.75 & 5.33 & 1.84 & 3.27 & 6.98 & 20.95 & 11.34 \\
\hline \multirow[t]{4}{*}{ Total } & \multirow[t]{4}{*}{-} & $2013 / 2014$ & 0.25 & 10.00 & 1.45 & 5.44 & 8.04 & 24.12 & 16.63 \\
\hline & & $2014 / 2015$ & 0.25 & 8.00 & 1.39 & 4.44 & 6.84 & 20.52 & 14.76 \\
\hline & & $2015 / 2016$ & 0.50 & 6.00 & 1.61 & 4.35 & 8.97 & 26.91 & 16.71 \\
\hline & & $\begin{array}{l}\text { Yearly } \\
\text { average }\end{array}$ & 0.33 & 8.00 & 1.48 & 4.74 & 7.95 & 23.85 & 16.03 \\
\hline
\end{tabular}

${ }^{1}$ Cropping year (n-1/n) correspond to the period from April of the year before (n-1) to March of the following year (n)

${ }^{2}$ A vehicle of 3 tons is used for the transport of cassava harvested to markets.

\section{Cassava commercialization aspects}

The Table 6 presents cassava commercialization aspects in Côte d'Ivoire. The cassava harvesting and marketing was globally permanent (28.26\% of farmers) in the year or frequently realized from January to March (25.36\%), October to December (18.12\%), April to June (15.94\%) and July to 
September $(12.32 \%)$. The analysis between localities of agro ecological regions revealed different periods of commercialization. The main markets supply periods were January to March for both localities Man (50\%) and Bingerville (40\%) and from July to September for Bonoua (50\%) while it was permanent for both localities Bouake (51.85\%) and Dabou (52\%).

Actors involved in the value chain of cassava were composed of transformers $(60.32 \%)$, wholesalers $(17.46 \%)$ and retailers $(9.52 \%)$. The presence of actors who cumulate two (2) functions such as wholesalersretailers $(6.35 \%)$, wholesalers-transformers $(5.56 \%)$ and transformersretailers $(0.79 \%)$ was observed. In the value chain, transformers are generally in great proportion except in the localities of Bonoua (wholesalers (63.33\%) and wholesalers-transformers $(23.33 \%)$ and Bouake (retailers $(33.33 \%)$. Destinations of cassava products are wholesale $(40.80 \%)$ or retail markets $(12 \%)$ as well as households (47.20\%). Main destinations were wholesale markets in Man (62\%) and Bonoua (97.67\%) while it was households in Bouake (89.47\%), Dabou (89.47\%) and Bingerville (86.21\%).

Average markets prices were $33.23 \mathrm{~F} \mathrm{CFA} \mathrm{/} \mathrm{Kg} \mathrm{at} \mathrm{the} \mathrm{farm} \mathrm{gate} \mathrm{level}$ and $51.21 \mathrm{~F} \mathrm{CFA} / \mathrm{Kg}$ on wholesales markets for fresh tuber of cassava. Contrary to localities of Bouake and Bonoua where vehicles of 3 tons were often used for cassava commercialization, in the localities of Man, Dabou and Bingerville, bags were used. Due to the unknown weight of bags, estimation of markets prices in these localities was challenging.

Table 7 : Cassava processing and commercialisation characteristics in Côte d'Ivoire

\begin{tabular}{|c|c|c|c|c|c|c|}
\hline Agro Ecological Region & West & Centre & South & & & Pooled \\
\hline Locality & Man & Bouake & Dabou & Bonoua & Bingerville & \\
\hline \multicolumn{7}{|l|}{$\begin{array}{l}\text { Harvests and } \\
\text { Markets supply periods }{ }^{1} \\
(\%)\end{array}$} \\
\hline Permanent & - & 51.85 & 52.00 & 6.67 & 33.33 & 28.26 \\
\hline January to March & 50.00 & 7.41 & 16.00 & 13.33 & 40.00 & 25.36 \\
\hline April to Jun & 46.15 & 3.70 & 8.00 & 13.33 & 10.00 & 15.94 \\
\hline July to September & - & - & 8.00 & 50.00 & - & 12.32 \\
\hline October to December & 3.85 & 37.04 & 16.00 & 16.67 & 16.67 & 18.12 \\
\hline \multicolumn{7}{|l|}{ Actors $(\%)$} \\
\hline Transformers & 66.67 & 66.67 & 78.95 & - & 100 & 60.32 \\
\hline Wholesalers & - & 16.67 & - & 63.33 & - & 17.46 \\
\hline Retailers & 33.33 & - & 10.53 & - & - & 9.52 \\
\hline Wholesaler - retailers & - & - & 5.26 & 23.33 & - & 6.35 \\
\hline $\begin{array}{l}\text { Wholesaler - } \\
\text { transformers }\end{array}$ & - & 16.67 & - & 13.33 & - & 5.56 \\
\hline Transformers - retailers & - & - & 5.26 & - & - & 0.79 \\
\hline \multicolumn{7}{|l|}{ Destinations (\%) } \\
\hline Wholesale markets & 62.07 & 22.22 & - & 97.67 & - & 40.80 \\
\hline Retail markets & 31.03 & - & 10.53 & - & 13.79 & 12.00 \\
\hline Households & 6.90 & 77.78 & 89.47 & 3.33 & 86.21 & 47.20 \\
\hline
\end{tabular}




\begin{tabular}{lllllll}
\hline $\begin{array}{l}\text { Markets Prices (F } \\
\text { CFA/Kg) }\end{array}$ & \multicolumn{7}{l}{} \\
\hline Producer & 10.83 & 8.33 & - & 32.55 & 21.66 & 26.16 \\
Min & 13.75 & 19.16 & - & 55.12 & 30.26 & 40.31 \\
Max & 12.29 & 13.74 & & 43.83 & 25.96 & 33.23 \\
Mean & & & & & & \\
\hline Wholesaling & - & - & 50.00 & 31.25 & - & 39.25 \\
Min & - & 15 & 66.66 & 72 & & 63.18 \\
Max & & 15 & 58.33 & 51.62 & & 51.21 \\
Mean & & & & & & \\
\hline
\end{tabular}

\section{Cassava processing and consumption characteristics}

The main characteristics of cassava consumption were described in Table 7. Results showed that traditional varieties were most consumed in Côte d'Ivoire. In cassava processing, variety Dabou (15.63\%) was mostly used for pounded cassava while Yace was processed as fermented paste $(49.45 \%)$ or dried cassava (54.31\%) for local foods Placali or Attiéké. The study revealed that frequencies of consumption were three times a week for pounded cassava, twice a week for Placali and daily for Attiéké.

The analyses within agro ecological regions showed differences. Contrary to the West region (Man) where variety Dabou was used for pounded cassava, other traditional varieties were used in the Centre (Agba ble (40.74\%) in Bouake) and in the South (Akra-batchin (66.66\%) in Bonoua and 'Manioc bois rouge' in Abidjan (36.36\%) and Bingerville (45\%)). It was also found that contrary to the localities of Man and Bonoua where pounded cassava was most consumed ( $89.29 \%$ and $66 \%$ ), dried cassava (Attiéké) food was the most consumed in other localities surveyed.

This study showed that traditional varieties of cassava were still well consumed in Côte d'Ivoire. The wide type of product consumed was dried cassava or Attiéké and the traditional variety Yace seems to be well adapted and most used by transformers in different agro ecological regions investigated. It is well known that Attiéké was the largest cassava processing product in Côte d'Ivoire (Coulibaly et al., 2014). The adaptability of improved varieties for food processing in dried products like Attiéké should be reinforced. This study did not highlight the problems and challenges prohibiting actors in cassava processing from realizing the expected yield in terms of production thereby affecting their profit. Indeed, the operations involved in Attiéké's production were essentially the same as for gari: peel and wash, chop (in 3-4 cm cubes), crush or grate, drain, sift, granulate, dry and steam. The production process was very long and sometimes tedious, most operations still being done by hand, except for grinding (Coulibaly et al., 2014). On this subject, Ehinmowo \& Fatuase (2016) showed, in the case of the adoption of improved cassava processing technologies by women entrepreneur in the south-west of Nigeria, that the high cost of equipment, the 
non-availability of the equipment, the difficulty to operate the machines and the lack of knowledge were the major challenges affecting the adoption of the improved cassava processing technologies.

Table 8 : Cassava consumption characteristics in households in Côte d'Ivoire

\begin{tabular}{|c|c|c|c|c|}
\hline $\begin{array}{l}\text { Agro } \\
\text { Ecological } \\
\text { Region } \\
\text { (Locality) }\end{array}$ & Variety preferred & $\begin{array}{l}\text { Frequency } \\
(\%)\end{array}$ & $\begin{array}{l}\text { Modality of } \\
\text { consumption }\end{array}$ & $\begin{array}{l}\text { Frequency } \\
(\%)\end{array}$ \\
\hline \multicolumn{5}{|l|}{ West (Man) } \\
\hline $\begin{array}{l}\text { Pounded cassava } \\
\text { Fermented paste } \\
\text { Dried cassava } \\
\end{array}$ & $\begin{array}{l}\text { Dabou } \\
\text { Yace } \\
\text { Yace }\end{array}$ & $\begin{array}{l}89.29 \\
95.83 \\
80.00 \\
\end{array}$ & $\begin{array}{l}\text { Three times per week } \\
\text { Three times per week } \\
\text { Once a week }\end{array}$ & $\begin{array}{l}35.71 \\
37.50 \\
60.00 \\
\end{array}$ \\
\hline \multicolumn{5}{|l|}{ Centre (Bouake) } \\
\hline $\begin{array}{l}\text { Pounded cassava } \\
\text { Fermented paste } \\
\text { Dried cassava } \\
\end{array}$ & $\begin{array}{l}\text { Agbable } \\
\text { Agbable } \\
\text { Yace } \\
\end{array}$ & $\begin{array}{l}40.74 \\
44.83 \\
69.23 \\
\end{array}$ & $\begin{array}{l}\text { Everyday } \\
\text { Twice a week } \\
\text { Everyday } \\
\end{array}$ & $\begin{array}{l}20.69 \\
23.33 \\
72.41 \\
\end{array}$ \\
\hline \multicolumn{5}{|l|}{ South } \\
\hline \multicolumn{5}{|l|}{ Abidjan } \\
\hline Pounded cassava & $\begin{array}{l}\text { Manioc bois } \\
\text { rouge }\end{array}$ & 36.36 & Once a week & 27.27 \\
\hline Fermented paste & Yace & 80.00 & Once a week & 50.00 \\
\hline Dried cassava & Yace & 86.67 & Everyday & 88.89 \\
\hline \multicolumn{5}{|l|}{ Bingerville } \\
\hline Pounded cassava & $\begin{array}{l}\text { Manioc bois } \\
\text { rouge }\end{array}$ & 45.00 & Twice a week & 28.00 \\
\hline Fermented paste & Yace & 66.67 & Once a week & 21.05 \\
\hline Dried cassava & Yace & 90.48 & Everyday & 37.04 \\
\hline \multicolumn{5}{|l|}{ Bonoua } \\
\hline Pounded cassava & $\begin{array}{l}\text { Akra batchin, } \\
\text { Mantale }\end{array}$ & 66.66 & Everyday & 46.67 \\
\hline Fermented paste & Yace & 55.56 & Twice a week & 44.44 \\
\hline Dried cassava & Yace & 69.23 & Three times a week & 38.46 \\
\hline \multicolumn{5}{|l|}{ Dabou } \\
\hline Pounded cassava & $\begin{array}{l}\text { You M'Bossi, } \\
\text { Bonoua }\end{array}$ & 45.45 & Three times per week & 21.43 \\
\hline Fermented paste & Yace & 40.00 & Once a week & 23.81 \\
\hline Dried cassava & Yace & 25.00 & Everyday & 65.52 \\
\hline \multicolumn{5}{|l|}{ Pooled } \\
\hline Pounded cassava & Dabou & 15.63 & Three times per week & 20.53 \\
\hline Fermented paste & Yace & 49.45 & Twice a week & 22.86 \\
\hline Dried cassava & Yace & 54.31 & Everyday & 55.37 \\
\hline
\end{tabular}

\section{Conclusion}

The current state of cassava production and technology level as well as commercialization and consumption aspects were analyzed in Côte d'Ivoire. The collected data showed that production, commercialization and consumption of traditional varieties are still higher comparatively to improved varieties introduced in agro ecological regions. Basing on high yields of improved varieties and the great desire of cassava growers to adopt new cassava technologies, research and extensions services should be reinforced taking into account sensitization and socio-agro ecological specificities. These 
problems need to be addressed in order to increase the level of adoption and to accrue more profits.

\section{Acknowledgement}

The funds for this survey were graciously donated by the Korea Africa Food \& Agriculture Cooperation Initiative (KAFACI)

\section{References:}

1. Agbamu, J.U. (2006). Essential of Agricultural Communication in Nigeria. Malthouse Press Limited, 11B Gorola Street, Off Adeola Victoria Island, Lagos, 2006.

2. Burns, A., Gleadow, R., Cliff, J., Zacarias, A. \& Cavagnaro, T. (2010). Cassava: The Drought, War and Famine Crop in a Changing World. Sustainability 2010, 2, 3572-3607. doi:10.3390/su2113572

3. CNRA (2014). Le CNRA en 2014 www.cnra.ci/downloads/Le_CNRA_en_2014.pdf

4. Coulibaly, O., Arinloye, A.D., Faye, M. \& Abdoulaye, T. (2014). Regional cassava value chains analysis in west africa: regional summary. Technical Report January 2014 DOI: 10.13140/2.1.2510.2403

5. Ehinmowo, O.O. \& Fatuase, A.I. (2016). Adoption of Improved Cassava Processing Technologies by Women Entrepreneur in South West, Nigeria World Journal of Agricultural Research, 2016, Vol. 4, No. 4, 109-113 Available online at http://pubs.sciepub.com/wjar/4/4/2 (C) Science and Education Publishing DOI:10.12691/wjar-4-4-2

6. Ekong, E.E. (2003). An Introduction and Analysis of Rural Nigeria (Second Edition), Dove Publishers Limited, Uyo, Nigeria pp 369, 2003.

7. FAO (2013). FAOSTAT. http://faostat.fao.org/site/339/default.aspx

8. FAO (2017). Food Outlook: biannual report on global food markets. Biannual report, Rome, 41 p. http://www.fao.org/3/a-I8080e.pdf

9. IFAD \& FAO (2000). "The World Cassava Economy, Facts, Trends and Outlook," International Fund for Agricultural Development and Food and Agriculture Organization of the United Nations, Rome, 2000. http://www.scribd.com/doc/48938803/The-world-cassavaeconomy-I IITA, Ibadan, Nigeria.

10. Nweke, F.I. (2004). New Challenges in the Cassava Transformation in Ghana and Nigeria. IFPRI Discussion Paper no. 118.

11. Nweke, F.I. (1994). Processing Potentials for Cassava Production Growth. Working Paper No. 11. Collaborative Study on Cassava in Africa International Institute of Tropical Agriculture, Ibadan, pp.50$52,1994$. 
12. N'zué, B., Zohouri, G. P., Djédji, C. \& Tahou, O. (2013). Bien cultiver le manioc en Côte d'Ivoire. Fiche tech, 4p. http://lorbouor.org/agrituto/manioc.pdf

13. N'zué, B., Zohouri, G. P., Doumbia, S., Yapi-Gnaoré, V. \& Sangaré, A. (2008). Le recépage du manioc, une technique rapide de multiplication https://www.agrici.net/wpcontent/uploads/2016/12/ftech_recepage_manioc_ver2008.pdf

14. N'zué, B., Okoma, M.P., Kouakou, A.M., Dibi, K.E.B., Zohouri, G.P., Essis, B.S. \& Dansi, A.A. (2014). Morphological Characterization of Cassava (Manihot esculenta Crantz) Accessions Collected in the Centre-west, South-west and West of Côte d'Ivoire. Greener Journal of Agricultural Sciences. 4(6):220-231.

15. Sayre, R., Beeching, J. R., Cahoon, E. B., Egesi, C., Fauquet, C., Fellman, J.\& Zhang, P. (2011). The BioCassava plus program: Biofortification of cassava for sub-Saharan Africa. Annual review of plant biology, 62, 251-272

16. Scott, G. J., Rosegrant, M. W. \& Ringler, C. (2000). Roots and tubers for the 21st century: Trends, projections and policy options. Food, Agriculture and Environment Discussion Paper 31, International Food Policy Research Institute (IFPRI), Washington D.C.

17. Suleman, A. (2012). Factors Influencing Adoption of Improved Cassava Processing Technologies by Women Processor in AkokoEdo, Edo State. Faculty of Agriculture, Ahmadu Bello University, Zaira, Nigeria. Published Thesis, 2012.

18. Yusuf, H.O. (2009). Factors Influencing Adoption of Improved Groundnut Oil Processing Technologies by Rural Women in Kaduna State, Nigeria. Unpublished M.Sc. Thesis, Department of Agricultural Economics and Rural Sociology, Ahmadu Bello University, Zaria, 2009. 